\title{
The 1958-62 Chinese Famine and Its Impact on Ethnic Minorities
}

\author{
Lucien Bianco
}

L'École des Hautes Études en Sciences Sociales

\begin{abstract}
China underwent its most murderous famine between 1958 and 1962 . Although a demographic transition from the countryside to the cities was in its early stage and gross domestic product (GDP) per capita was among the lowest in the world, objective conditions were far less decisive than Chinese Communist Party (CCP) policies in bringing about the famine. A development strategy copied on the Soviet model favoured quick industrialization at the expense of rural dwellers. Such novelties as people's communes, communal canteens, and backyard furnaces further aggravated the famine. Though ethnic minorities represented only 6 percent of China's population, compared to forty-seven percent in the Soviet Union, Soviet nationality policies heavily influenced those of China. Initially mild, especially for Tibetans, Chinese nationality policies became more authoritarian with the advent of the Great Leap Forward in 1958. Qinghai Tibetans resisted the closure of many monasteries; then the same policies, and famine itself, caused a more important rebellion in 1959 in Xizang (Tibet). Repression and the flight of the Dalai Lama to northern India coincided with the end of Tibet's special status in China.

Internal colonialism did not, however, aggravate the impact of famine on national minorities in China. Their rate of population growth between the first two censuses (1953 and 1982) exceeded that of Han Chinese. Among the provinces most severely affected by famine, only Qinghai was largely inhabited by ethnic minorities. Within Qinghai the same pattern prevailed as in Han populated provinces: the highest toll in famine deaths was concentrated in easily accessible grain surplus areas. The overwhelming majority of victims of the Chinese famine were Han peasants. At most, 5 percent were members of ethnic minorities, compared to eighty percent of victims in the Soviet Union in the period between 1930 and 1933.
\end{abstract}

Keywords: famine, China, national minorities, Tibetans, Qinghai.

\section{THE FAMINE IN CHINA}

$\mathbf{T}$ he most murderous famine in human history killed between 20 and 40 million people in China between 1958 and $1962 .{ }^{1}$ Although the most murderous in absolute terms, it killed fewer people in proportion to the

\footnotetext{
${ }^{1}$ Estimates of excess mortality vary between 15 and 46 million, the most frequent being in the 30-36 million range. See, among others, Yang, Tombstone 427-30.
} 
total population than did the Khmer famines in Cambodia between 1975 and 1979 (Ó Gráda 24), and many fewer than the 1930-33 famine in Kazakhstan and the 1932-33 Holodomor in Ukraine (Rudnytskyi et al.). The overall proportion of famine deaths in the Soviet Union in 1930-33 was slightly less, given that China's population in 1958 was roughly four times that of the USSR in the early 1930s (Bianco 125).2

During the worst years of the Chinese famine (1959-61), some starving people extended their lives by a few weeks - or hastened their deaths - by eating anything at hand-by cutting up carrion flesh, fishing dead rats out of cesspits, or eating a mixture of earth and weeds called "Guanyin's earth" (after the goddess of mercy) that filled their stomachs before blocking their intestines completely, because it could be neither digested nor evacuated. Others ate flesh from dead bodies found along the roadside. Nor did people refrain from eating members of their own families who had died at home. Sometimes they even killed them. Children were not allowed to go out for fear they could be killed; there were cases where mothers strangled, cut up, and boiled their own children, some having lost their minds. Rather than eating their own children, people would exchange their children with children of their neighbours, each surviving thanks to the other's offspring. In one district in Anhui, an especially badly hit province, this was not a rare practice and was called "yi zi er chi" ("exchanging children for eating"). ${ }^{3}$

\section{Pretexts and Valid Excuses for Famine}

The Chinese Communists first hid the famine and later referred to 1959-61 as the "three bad years," using natural disasters as an explanation for the death toll. Some regions of the country did suffer from bad weather in 1959 and 1961, and others experienced a drought in 1960, but one author (Jisheng Yang) found that within a 27-year period (1956-83), eleven years of bad weather conditions and even natural disasters affected more regions than in 1959-60 without causing famine, or even a noteworthy drop in cereal production (Tombstone 452-56). What is true is that agriculture was vulnerable to vagaries in the weather-agricultural production, being highly unstable because it depended on rainfall, was unreliable enough for the government to be able to blame the famine on natural causes.

Another excuse for the death toll pointed to Nikita Khrushchev, who recalled the Soviet experts in China in the summer of 1960. Putting aside the

\footnotetext{
${ }^{2}$ See my comparison of the Soviet and Chinese famines in Bianco 125-66.

3 The expression "exchanging children for eating" had been in use for centuries, so much so that it may have been more often spoken than actually implemented.
} 
fact that Mao Zedong, Chairman of the People's Republic of China (PRC), had done everything possible to provoke that recall, it had practically no impact on agricultural production. There were indeed very few agronomists among the Soviet specialists, and Khrushchev had twice offered to send help but was haughtily turned down (Dikötter 111).

The one argument that would have carried some weight was not mentioned by Chinese propaganda, namely, a demographic transition that was still in its early stages, with fertility rates at high levels and mortality rates falling rapidly. Mortality was falling far more quickly in China than it had during the first decade of the Soviet rule, if only because the fight against infectious diseases worldwide was far more effective in the 1950s than in the 1920s. Apart from China's chronological advantage, the Chinese regime in fact contributed to the fall in mortality rates during the eight years preceding the disaster of the Great Leap Forward (Banister 56). Against the background of this spectacular fall in mortality rates, the famine appears even more deadly, for had mortality remained at pre-1949 levels, quite a few of those who died of hunger would not have survived until 1958. Given that the birth rate did not begin to decline noticeably until the 1970s, the natural population increase was very rapid during the first phase of the demographic transition, at between 2 and 2.5 percent per year between 1954 and 1957 (Banister 352).

Furthermore, urbanization in China was proceeding more quickly than population growth. It started from very low levels, with an urban population in 1957 of fifteen percent, and rose by more than 8 percent in 1958, and by fifteen percent in 1959. In that year alone, China's urban population increased by 16.5 million (from 107.2 million to 123.7 million), a record that was surpassed the following year (Banister 330-31; Lardy 369). That rapid urbanization was less due to natural growth, which was slower in the cities than in the countryside, than to a hasty rural exodus triggered by break-neck industrialization. Most of the migrants were young peasants. Given the surfeit of rural labourers, the migrants easily could have been replaced in the fields had the Great Leap Forward (GLF) not mobilized the workforce for enormous hydroelectric projects and small backyard furnaces.

This rapid urbanization was the corollary to an unrealistic development strategy, but development as such was an inevitable course. The slow start to the demographic transition went hand in hand with economic underdevelopment. In 1949 China's gross domestic product (GDP) per capita was among the lowest in the world and remained so until the eve of the fateful GLF (Wemheuer 27, 270n4). A classic study entitled China: Land of Famine published by Walter Mallory in 1926 rightly implied that famine had long been endemic in China. A famine had killed some ten million people in the north and the northwest of the country between 1928 and 1930, and there were famines in 1920-21 (in north China) and 1943 (in Henan 
province) (Lillian Li 304). However, each of these famines paled in comparison to the awful famine that had hit imperial China between 1876 and 1879.

Famine in China: From the Great TuRning Point to the Great LEaP ForWARD

\section{Modernization and Development Strategy}

Mao loved to praise the virtues of "negative examples," mercilessly pointing them out from among the ever-criticized class enemies in order to educate the heirs of the 1911 Chinese revolution that overthrew China's last imperial dynasty (the Qing dynasty) and established the Republic of China (ROC). But did he learn any lessons from the negative example provided by the tragedy of 1931-33? Apparently he did, because in 1958 he inaugurated a "Chinese way" that departed from the model he had unswervingly followed until that point. This claim to originality would have been praiseworthy had the new model corrected the aberrations of the original, but it did not.

Mao criticized the Stalinist development strategy and altered his own, but his corrections did not factor in a famine that was distant in both time and space and about which he knew very little. The first Chinese Five-Year Plan (1953-57) can be credited with accelerated industrial construction, but it also confirmed that it was no longer possible to continue neglecting agriculture. That sector had received only 7 percent of the plan's total investment, compared with 46.5 percent for heavy industry. The emphasis on expensive technology had drawn abundantly on the country's meagre capital resources but very little on the over-abundant workforce. It was in part to remedy that imbalance that the Great Leap Forward was concocted during the winter of 1957-58.

Unfortunately, the necessary readjustments in agriculture and the consumer industries were not accomplished at the expense of heavy industry. If industry had benefitted disproportionately in the past, it benefitted still more in 1958, obtaining 57 percent of the total investment versus 46.5 percent. In 1959 that investment reached an historic record of 43.4 percent of the country's gross domestic product. Steel, that symbol of modernity and power, demanded maximum effort, as witnessed by the cascade of quotas that followed one after the other in the space of a few months: from 6.2 million tonnes (annual production) in February 1958, already a sixteen percent increase over the 5.35 million tonnes produced in 1957, to eleven and then twelve million tonnes, as reported in three speeches Mao made in early September of that year (MacFarquhar 89-90). 
As in the USSR a generation earlier, the rural economy and rural societies in China paid the price of an accelerated industrialization program; in both countries a similar development strategy led to excessive monetary transfers from agriculture to heavy industry. In some respects, the GLF was an exaggerated reproduction of the first Soviet Five-Year Plan (1928-32). Production targets that were already "teleological" during the first Soviet Plan became more so during the Chinese GLF (Graziosi, Histoire 76-77). In both Soviet Union and China, a direct cause of famine was excessive and ruthless grain requisitioning from producers that continued well after the famine had started.

\section{Famine Aggravated by Novelties}

In China, an overambitious industrialization strategy was made more dangerous by novelties that the party experimented with and often forcibly imposed. A huge increase in the production of steel was to come in part from small backyard furnaces, which between seventy and ninety million peasants (sources differ)-mostly peasant women-were busy stoking, using rudimentary techniques. To keep those furnaces going, the local communist cadres seized saucepans, stoves, scissors, knives, spades, pickaxes, bicycles, iron railings, door knockers, and temple bells to produce such mediocre steel that nine-tenths had to be thrown away as scrap (Yang, Tombstone 28, 177; Stèles 309).

Having lost their kitchen utensils, people could no longer cook in their own homes. Everyone ate in the communal canteens, which served free food provided by the newly created People's Communes. Canteens wasted food as a result of sloppy management, privileges, and corruption. According to one student of the famine, canteens may have been responsible for one third of the total number of deaths from starvation (Yang, Tombstone 191).

During China's First Five-Year Plan (1953-57), agricultural cooperatives became responsible for agricultural production following collectivization. The far larger People's Commune, created on the scale of the massive projects it was supposed to undertake, was charged with speeding up social evolution and carrying out a veritable transition from a family framework to a community one. Was the commune the social counterpart of the economic Great Leap Forward? This was hoped a little and claimed a great deal. Preaching by example, many People's Communes in Henan province (where the first commune was founded) ceased to distribute work points (which enabled working members to buy necessities) because everything was supposedly free-not only food, but clothing, education, medical care, weddings, and funerals. Without going that far, other communes abolished private plots, which were deemed as useless as personal pots and pans, given 
the impending advent of "each according to his need." Propaganda even hinted that the arrival of the Communist society was just around the corner. "Dizzy with success" or not, China was proceeding faster than the Soviet model-within a few months, ninety-nine percent of the peasants had become members of People's Communes.

Mobilized in almost military fashion, commune members went to work in squads. The peasants were "soldiers on the agricultural front." This metaphor betrayed the true ambition of the GLF, which was less social than economic: the mobilization of the masses to industrialize the nation and to forge workers out of peasant foot soldiers. In a matter of weeks, some sixty million villagers were packed off to water projects near and far, small and large. In no time they had built numerous dams and dug countless irrigation ditches, all with the most rudimentary tools, working day and night in shifts to the sound of martial music blaring from loudspeakers. But since the projects were designed by peasants rather than engineers, and built from earth, corn cobs, and bamboo rather than cement, many of the constructs washed away in the first floods. Many of the dams and reservoirs that survived reduced the yields they were supposed to improve with irrigation, for in their haste to get the job done quickly, cadres of peasants often dispensed with provisions for drainage. As a result of subsequent evaporation, salts built up in the reservoir water and intensified the salinity of the soil during irrigation.

The mobilization of a female labour force, now "liberated" from domestic tasks thanks to communal canteens, did little to offset the shortage of labour that was a consequence of those projects and the rural furnaces. In addition, there was an exodus to the cities, which boosted the workforce in modern industry from just over nine million in 1957 to more than twentyfive million in 1958. Chairman Mao ordered the mechanization of agriculture, but such fast-track industrialization could not be carried out at the drop of a hat. In the meantime, sickles, spades, and pickaxes would have been welcome, but they had been melted down in the furnaces. As a result of the labour shortage, a portion of the bumper harvest of 1958 began to rot in the fields. The GLF had achieved the seemingly impossible feat of creating a workforce shortage among the largest peasantry in the world.

\section{Blatant Lies}

Credit for the excellent harvest of 1958, the best since the Revolution of 1949, was attributed to the People's Communes and the GLF rather than to good weather. According to regional reports, 450 million tonnes of cereals were brought in that year, but Mao decided to be cautious and announced a harvest of 375 million tonnes. In the absence of reliable statistics, the official 
production figures for 1958 were thus decided by Chairman Mao, and it was on that basis that the 1959 production target was set at 525 million tonnes, while land to be sown was reduced by ten percent and land to be sown with cereals was reduced by thirteen percent. The leaders were now grappling with a thorny issue: what should they do with the surplus rice and wheat? Mao suggested that the peasants work in the morning and devote the rest of the day to educating themselves. In fact, at 197.6 million tonnes, compared with 195 million in 1957, the good harvest of 1958 exceeded that of the previous year by only1.33 percent. With less land sown and less favourable weather conditions, the 1959 harvest fell to 170 million tonnes. People were growing disillusioned even before they heard these poor results. By spring, in canteens where people had eaten their fill the previous fall, some foodstuffs were already running low. Matters grew worse after the harvest, for on the basis of those inflated harvest forecasts, grain procurement reached record levels, far above all the other excessive levies in Mao's lifetime: 67.4 million tonnes, nearly twenty million of which would later have to be returned to the starving peasants (Ash 970).

While not the sole cause, this pernicious process of wrong decisions made on the basis of blatant lies considerably aggravated the famine. The leadership had set an example for outrageous exaggeration that others followed, exhorting the populace: "Let's achieve the second Five-Year Plan in two years." The Communist Party cadres were under such pressure that they were "tempted to inflate figures at every level" (Xue Muqiao, in charge of statistics, was fired in 1959 because of his opposition to the compilation of deceptive local progress statistics at the sacrifice of national statistics, as suggested by Choh-Ming Li 111-12). The leaders were then taken in by the lies for which they, first and foremost, were to blame. The accumulation of successive lies at each level of the administrative hierarchy resulted in seriously distorted national figures. The production figures became so fantastic that the increase in cereal procurement quotas appeared reasonable. Unrelenting competition between cadres impelled them to try harder to surpass their neighbours, to launch satellites ever higher in the skies. In this case, the Sputnik-level accomplishments were to be previously unheard of yields, ${ }^{4}$ not to mention agricultural products prodigious in their size and volume: sixty-kilo pumpkins, one-pound ears of corn, wheat growing so densely that it could bear the weight of three children, and so on (Teiwes and Sun 123). In 1958 the convoy transporting Mao to the centre of the Xushui model commune in Hubei province passed turnips, cabbages, carrots, and other vegetables piled up along the roadside for more than a $l i$

\footnotetext{
${ }^{4}$ Becker, La grande famine 176. MacFarquhar 127 ("sputnik" fields: Deng Xiaoping himself believed a peasant who claimed to have harvested 35 tonnes of rice on one $m u$ of land, in other words, on 660 square meters).
} 
(a third of a mile). Mao was told in all seriousness that the peasants had thrown them there, not knowing what to do with such excess. The commune's Party secretary confirmed this, saying: "Here everybody eats five meals a day for free" (Teiwes and Sun 123). In the words of Mao's personal doctor, "The whole of China was a theatre, and everyone redoubled their efforts at exaggeration to please Mao" (Zhisui Li 302). ${ }^{5}$

LATE AWAKENING, LUSHAN, AND POST-LUSHAN RELAPSE

\section{Late Awakening}

Despite this spectacle, Mao was not duped for long by the fantastical reports that came to him from the provinces. During the winter of 1958-59, it became clear that notwithstanding the good harvest, grain procurement deliveries were below forecast and there was a risk of food shortages in the cities, where populations had risen considerably. In collusion with the local cadres, the peasants had held back a portion of the harvest. Some provincial leaders wanted to lead a merciless anti-concealment campaign, but Mao declared his sympathy with those peasants driven to this kind of passive resistance by overzealous levies: "I now support conservatism. I stand on the side of right deviation. I am against egalitarianism and left adventurism" (speech on 5 March 1959, qtd. in Dikötter 86). As early as December 1958 Mao warned that the advent of Communism would have to wait.

One sign of the changing times was the (provisional) return of Chen Yun (1905-95). Chen, a member of the Permanent Committee of the Politburo and fifth in line in terms of power in the regime, was in charge of the economy and the only leader who had opposed the GLF strategy from the start, which had led to him being shunted aside. In the spring of 1959, he visited Henan, the vanguard province for utopian political activism, but he did not believe a single word or number of the fairy tales spun by the regional leaders. Mao himself gave the following instructions to the party cadres in a letter dated 29 April 1959: "Fixing production targets must be based on realities .... State exactly how much you have harvested and refrain from making false statements that are contrary to facts" (MacFarquhar 171). In June, without batting an eye, Mao seems to have accepted Chen Yun's proposal to reduce the steel production quota for 1959.

\footnotetext{
5 See also Becker, La grande famine 110, 121-22, 176. A trick photograph published in China Pictorial in 1958 and reproduced in Manning and Wemheuer (55) shows not three but four children standing on rice plants, the stool beneath them artfully concealed.
} 
Lushan (July-August, 1959)

Overall, a good half year, from November 1958 to June 1959, was devoted to "consolidation," the standard euphemism for retreat. At the end of June, 1959, when Mao went to Lushan (Jiangxi province) to preside over the leadership's summer meeting, he appeared resolved to confirm his rejection of exaggerations, illusions, and imbalances, as symbolized by Chen Yun's return to favour. Another leader, Marshal Peng Dehuai, Minister of Defence, had also made some enquiries in four provinces and drawn the same conclusions as Chen. Peng was the son of a poor peasant himself, something quite unusual in the Party leadership, and had seen famine as a child; it had killed several of his brothers. So, Peng plucked up his courage and went to see Mao in Lushan to persuade him to go still further in correcting his GLF strategy. Thwarted in making his case face-to-face because Mao was asleep (even more than Stalin, Mao was a night owl, who slept part of the day and imposed his rhythm on his entourage), Peng spent that night writing a letter to him. There was nothing really original in that letter, which expressed the unspoken opinions of the majority in the Party leadership, but Peng committed the crime of "lèse-majesté" by attempting to show what lessons could be drawn from the GLF experience-the prerogative of the Party leader. After criticizing the irresponsible slogans Mao had launched earlier, Peng attributed the left-wing errors of the past twelve months to "petitbourgeois fanaticism" in terms resembling those used by Lenin to denounce left-wing Communism as "an infantile disorder" (Teiwes and Sun 202-12; MacFarquhar 212-16; Yang, Tombstone 355-60; Union Research Institute 713).

That was more than Mao could take. He could criticize himself, but for someone else to criticize him was intolerable. Mao chose to interpret that private letter, written to urge him to pursue a retreat he had already begun, as a political attack. The majority of the leaders were as surprised as Peng by the ferocious assault that followed, but then sided with Mao in criticizing Peng. Mao gave them no choice: they could either support the president or follow the militaristic "plotter" Peng. The army remained silent, but just to make sure, Mao sent an ultimatum to his generals, stating: "If you take Peng's side, I will place myself at the head of the peasants and lead guerrilla warfare against you" (MacFarquhar 222). The Plenary Session of the Central Committee met on 2 August 1959 and condemned the right-wing opportunism of the anti-Party clique headed by Peng Dehuai. The warning was clear: anyone criticizing the GLF would be considered part of that clique of reprobates. 
Post-Lushan Relapse and Hecatomb (Late 1959 to Late 1961)

Lushan was not only one of the regime's turning points; it was the turning point for the famine. "Had the leadership reversed course in the summer of 1959 at Lushan, the number of victims claimed by famine might have been counted in the millions, and not in tens of millions" (Dikötter 103). ${ }^{6}$ Frank Dikötter's assessment illustrates a bitter truth: Peng's courage relaunched and aggravated the famine. The torrent of denunciations of right-wing opportunists and Peng's henchmen discouraged local cadres and provincial leaders from carrying out the adjustments they had begun earlier in the year. Anyone wanting to avoid being labelled a right-wing opportunist had to be careful not to challenge the validity of the People's Communes or the communal canteens. It was less dangerous to err on the left than to err on the right. At the end of 1959, the canteens were feeding four hundred million people, or more than seventy-two percent of the members of People's Communes (and nearly ninety-eight percent in Henan, one of the provinces in which the famine was most devastating). Again, a lethal frenzy had been launched but of a different magnitude than during the first phase of the GLF.

The 1962 harvest, while not as good as harvests from 1952 to 1959, was better than in the two previous years and helped to put an end to the carnage. A more decisive factor in stopping the famine, however, was the two measures that helped to reduce grain procurement quotas in the countryside, namely, increasing cereal imports and sending some twenty million recent arrivals to the cities back to their villages (Wemheuer 14247). While no one knows the exact number and year by year distribution of excess death, all agree that most people that had died from famine had died following the summer 1959 meeting of the Chinese Communist Party (CCP) leaders in Lushan, especially in 1960, a year about as lethal as the four years 1958, 1959, 1961, and 1962 taken together.

Table 1 compiles two estimates of the number of "abnormal" deaths. While their divergences illustrate our enduring ignorance, both estimates show that most deaths occurred from 1959 to 1961. Yang in Tombstone readily admits that his figures are based on much underestimated provincial data.

\footnotetext{
${ }^{6}$ Yang suggests that as a result of Lushan, the number of dead from starvation may have tripled, from twelve to thirty-six million (Tombstone 350).
} 
Table 1. Years versus "Abnormal" deaths (high and low estimates), according to Che Li 46-52; Yang, Tombstone 415; Yang, Stèles 501.

$\begin{array}{lll}1958 & 921,000 & 720,000 \\ 1959 & 4,819,000 & 4,750,000 \\ 1960 & 17,002,000 & 11,090,000 \\ 1961 & 8,476,000 & 3,000,000 \\ 1962 & 3,350,000 & 420,000 \\ & & \\ \text { Total } & \mathbf{3 4 , 5 6 8 , 0 0 0} & \mathbf{2 0 , 9 8 0 , 0 0 0} \\ & & \\ \text { II. RED CHINA AS AN EMPIRE } & \end{array}$

ETHNIC MinORITIES AND INTERNAL COLONIALISM

The Early 1950 s

Whereas ethnic minorities represented almost half (forty-seven percent) of the population of the Soviet Union in 1930, they comprised only six percent of the Chinese population in 1958. In the Soviet Union, minorities were officially distributed among fifty-five national minorities (although in reality there were more), which together amounted to less than one third (twenty-one percent) of the single Ukrainian nationality among the whole USSR population.

Though the question of dealing with ethnic minorities was therefore much less important for the Chinese than for the Soviet communists, the policies of these two governments were quite similar with respect to nationalities. The attitude of the CCP toward ethnic minorities was heavily influenced by the early policies of the USSR. Instead of republics and autonomous regions, the CCP merely established "autonomous regions." The Communist Party cadres for the autonomous regions were recruited from among the minorities, but as a rule, ultimate power rested with the Han secretary of the region's CCP Committee (Wemheuer 161-64).

Furthermore, Tibet, which had enjoyed independence from 1913 to 1951, was granted a special status. The CCP abstained from promoting social revolution in Tibet and did not interfere in the exploitation by monasteries of their estates. Inner Mongolia benefitted as well from the early tolerant policy of "indigenization," but became from 1949 the recipient of massive Han migration. The "Hanization" of the province 
followed. By the time of the 2000 census, Han represented seventy-eight percent of the population of Inner Mongolia. All other minorities were allowed a fair degree of self-rule between 1949 and 1957.

\section{The GLF Turning Point}

As in many other respects, the Great Leap Forward (GLF) was a turning point in policies toward minorities. While not established everywhere, People's Communes brought sudden and dramatic changes to most minority regions. Campaigns against local nationalism and well-known indigenous personalities were soon launched. Han cadres imbued with a spirit of "dahan zhuyi" ("great Hanism") endeavoured to "help their little brothers" by inciting them to get rid of religious superstitions and backward customs. At first, Tibet was exempted from such activist policies, but the exemption was limited to the autonomous region of central Tibet, Xizang. ${ }^{7}$ Many monasteries were closed in 1958 in Qinghai, where land and livestock were forcibly collectivized. An overambitious campaign to sedentarize nomads and turn grasslands into agricultural land was launched, reminiscent of the policy imposed a generation earlier on Kazakhstan (Wemheuer 170). It brought disastrous results, although less disastrous than in Kazakhstan. A huge number of cattle died here: their numbers decreased from fifteen million in 1957 to 10.8 million in 1958 and to 9.3 million in 1960 . The erstwhile nomads went hungry, and many Tibetans fled to Xizang (central Tibet). ${ }^{8}$ In Qinghai an important uprising linked to hunger involved more than one hundred thousand people. About half that number was arrested, as were many nomads who had fled the famine and were treated as "bandit rebels." Conflicts about collectivization, sedentarization, and the closure of monasteries had thus been turned into a rebellion against Han colonizers.

By the next spring, an even more important uprising, indeed the most serious armed rebellion ever suffered by the People's Republic of China (PRC), erupted in Xizang. It was suppressed by the People's Liberation Army in a matter of weeks, but in the meantime, mass demonstrations in Lhasa and the flight of the Dalai Lama to northern India had inaugurated a new era in Han-Tibetan relations. Tibet was no longer to be spared, and thereafter Beijing representatives in Lhasa directly ruled Xizang, like any

\footnotetext{
${ }^{7}$ A majority of Tibetans lived outside central Tibet, in the surrounding provinces to the east of Xizang, mostly throughout Qinghai province but also in western Sichuan, south-western Gansu, and northern Yunnan provinces.

${ }^{8}$ Some sixty thousand Tibetans, including a minority from Gansu, Sichuan, and Yunnan provinces, fled to central Tibet in 1960 (Wemheuer 299n64).
} 
other province. The end of Tibet's special status removed any remaining doubt about the internal colonialism promoted and maintained by the CCP as part of its Red Empire.

\section{EMPIRE AND EXCESS FAMINE DEATHS}

Natural Increase in Starvation Rates and Death Rates among Han and Minority Populations

A first rough indication in the rate of starvation in China is provided by the censuses of 1953 and 1982. In that twenty-nine-year span, the Han population grew at a rate of 1.9 percent per year, and the ethnic minorities grew at a rate of 2.2 percent per year. The latter rate obscures great discrepancies, which ranged from a low 1.2 percent for Tibetans (caused more by the flight to India of tens of thousands of Tibetans than by repression and excess famine deaths), to 2.4 percent for Hui and Miao, to 2.9 percent for Mongols (Aubin 303-04).

We know that the famine was less devastating among the ethnic minorities of Xizang, Xinjiang, and Inner Mongolia (where death rates remained under 2 percent even in 1960, the worst year) than in China as a whole. By contrast, autonomous minority counties in Yunnan recorded a high death rate of 2.62 percent in 1960, and the entire Guangxi Zhuang minority autonomous region endured the even higher rate of 2.94 percent (however, such higher rates remain well below those then affecting hundreds of millions of Han). In Guangxi and Yunnan, the leading cadres were mostly Han, who strictly implemented Beijing's murderous policies (Yang, Tombstone 397).

\section{Factors Aggravating Famine}

A key factor in an excess of unnatural deaths stems from the activist zeal demonstrated by some regional leaders in implementing Maoist radical policies. This was particularly the case in mostly Han-populated provinces, such as Anhui and Henan, where the famine was especially severe.

A second factor in large parts of the western periphery of China, largely inhabited by ethnic minorities, was the problem of delivering surplus grain to grain-deficit areas such as Xizang. The famine in Ukraine in the 1930s was caused by an opposite situation. Ukraine was a grain-surplus area, required to provide excessive amounts of grain to the state. 
The third factor is more complex but might have been the most important. In the China of 1958, as in the USSR in the 1930s, cities received the lion's share of the food. However, the industrial crop-growing areas adjacent to the main urban areas, as well as old industrial areas such as the northeast, were also given a food priority. Besides these privileged areas, the minority regions of western and northern China also belonged to the less severely afflicted famine areas, if only because they produced less grain and were harder to reach; thus, procurement quotas were set low or were nonexistent. As a rule, the areas most afflicted by severe famine were those surplus areas relatively well served by modern transport, and these areas were for the most part predominantly Han-populated (Garnaut 315-48; see especially 317-18).

\section{Highest Provincial Death Rates}

According to the most complete study of the Great Leap Forward famine, the rate of "unnatural" deaths during the famine was highest in Sichuan, Anhui, Gansu, Henan, Shandong, Qinghai, and Hunan provinces (Yang, Tombstone 394). With the exception of Qinghai, all provinces on this list were populated mainly (and some of them almost exclusively) by Han. The first and third provinces (Sichuan and Gansu) had some minorities (mostly Tibetan) in their western peripheries, but on the whole, Han and Tibetans suffered alike in Sichuan, Gansu, and Qinghai (Wemheuer 205). Qinghai province, which ranks sixth in terms of people lost to this famine, was the only one that was at the time mainly inhabited by ethnic, namely Tibetan, minorities.

Qinghai, the Most Severely Affected Minority Area in the Chinese Famine of 1958 to 1962

Unlike Ukraine in the 1930s, Qinghai in the 1950s, although a grain-deficit area, was able to import grain between 1953 and 1964 (Wemheuer 172). In 1960, during the acme of the famine crisis, Qinghai ranked fifth, not sixth, among the worst-affected provinces. ${ }^{9}$ Official figures (underestimates)

\footnotetext{
9 The highest mortality rates among China's twenty-eight provinces in 1960, the worst year of the famine, were as follows, per thousand: Anhui, 68.58; Sichuan, 53.97; Guizhou, 52.33; Gansu, 41.03; Qinghai: 40.73; Henan, 39.60 (Yang, Tombstone 394, Stèles 455). By contrast, the three largest cities and the northeast of China experienced the lowest mortality rates, per thousand: Shanghai, 6.8; Beijing, 9.2;
} 
counted 102,900 unnatural deaths from 1958 to 1962, a high percentage for a total population of 2,440,000 inhabitants.

\section{Figure 1. Map of Xining area, in eastern Qinghai10}

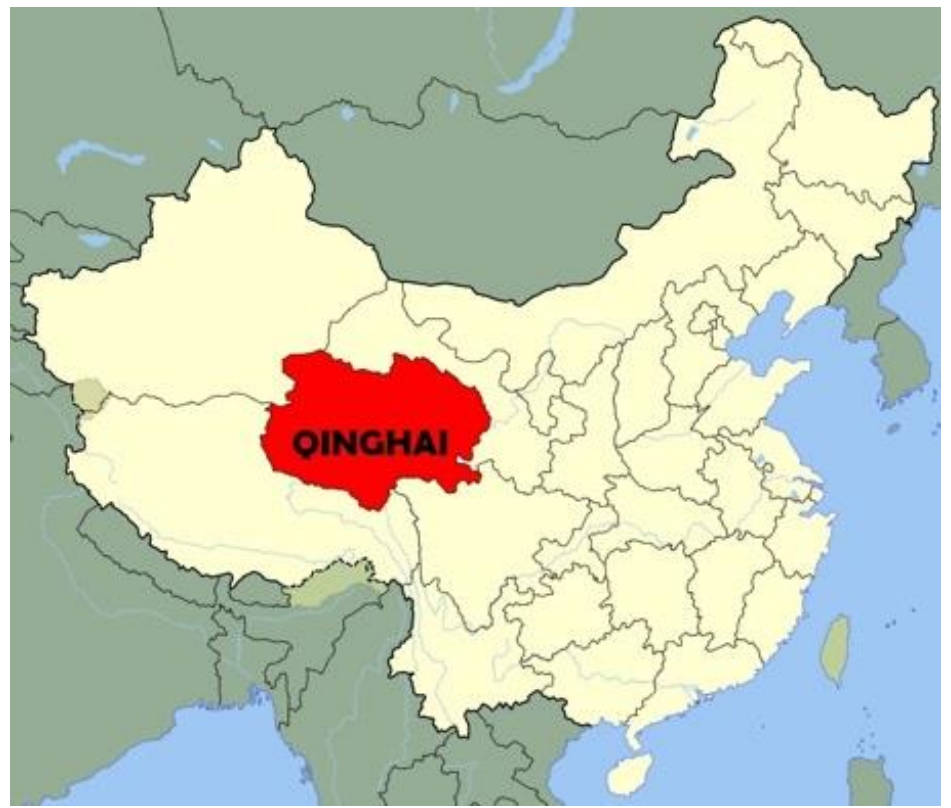

Inner Mongolia, 9.5; Jilin, 10.1; Tianjin, 10.3; Heilongjiang, 10.5; Liaoning: 11.5 (Dali L. Yang, Calamity 38).

10 "La province du Qinghai (en rouge) sur le territoire de la Chine," Wikipedia, https://fr.wikipedia.org/wiki/Qinghai\#/media/Fichier:China_Qinghai.svg. Accessed 8 Jan. 2021. 
Figure 2. Map (close-up) of Xining area, in eastern Qinghai11



Figure 3. Map: From Xining to Minhe, near the border with Gansu province $^{12}$

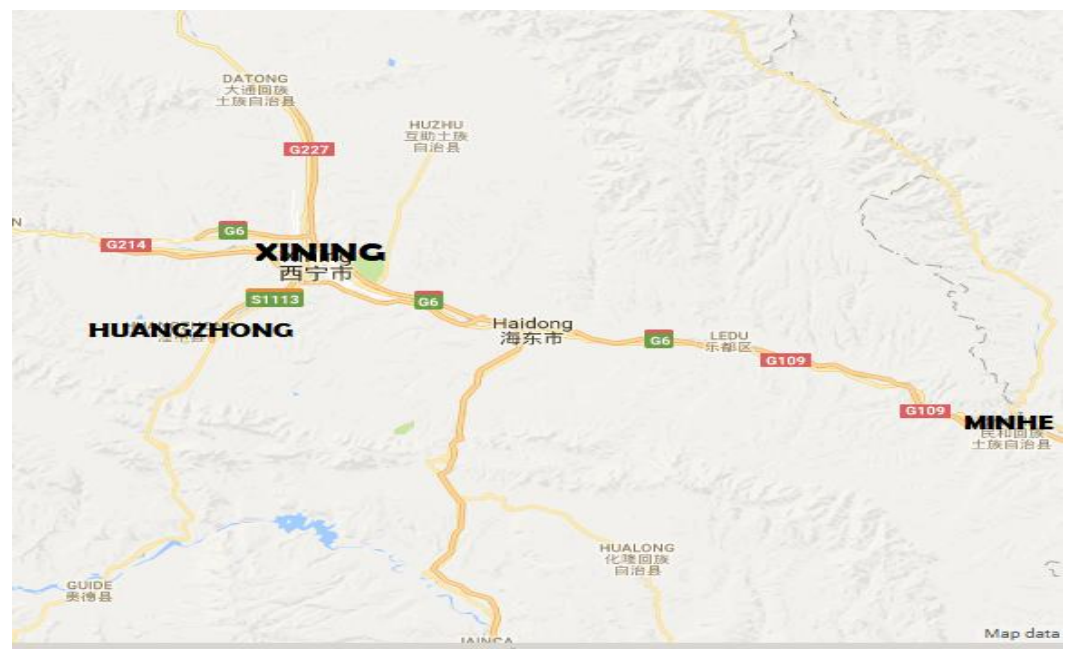

11 Zhonghua Renmin Gongheguo fen sheng dituji (Provincial Atlas of the People's Republic of China) 28.

12 Google Maps, https://www.google.com/maps/@36.4631395,102.079269,10.25z?hl=fr. Accessed 8 Jan. 2021. 
Figures 1, 2, and 3 depict the causal connection between modern transport and famine in Qinghai, with grain surplus areas located in the eastern, relatively accessible part of the province, being especially hard hit. This was indeed the case for Minhe county, located on the border with Gansu province, halfway between Lanzhou and Xining, respective capitals of Gansu and Qinghai provinces. Minhe county, renowned as a grain and fruit provider for the entire province, may have lost as many as twenty-five percent of its population between 1958 and 1960. More than 1 in 8 inhabitants of Huangzhong, another rich county, situated ten miles west of Xining, starved to death in 1960. Both Minhe and Huangzhong counties were sites of notorious cases of cannibalism, as well as especially harsh repression of dissenters, including people who dared to utter the mildest criticisms of authorities (Yang, Stèles 455-58). ${ }^{13}$

Some Qinghai Tibetans did indeed suffer an awful fate during the famine, but so did many more Han inhabitants of Sichuan, Anhui, Henan, and Shandong provinces. The worst case of mishandling the famine may have been the refusal to distribute the contents of silos located near the border between Henan and Hubei provinces to starving inhabitants of both provinces, almost all Han people.

In China as a whole, Han peasants constituted the overwhelming majority of the famine victims, and multi-ethnic borderlands such as Tibet, Xinjiang, and Inner Mongolia were "spared the worst of the famine" (Graziosi, "Stalin's and Mao's Famines" 93; Garnaut 337). Deaths from starvation among ethnic minorities amounted to some five percent of the total number of excess deaths, compared to eighty percent of the 1931-33 famine victims in Soviet Union, who happened to be Ukrainians, Kazakhs, or other nonRussians. Within China, we can merely compare the five percent of excess deaths among ethnic minorities to the six percent within China's total population. In other words, the great Chinese Famine did not kill, proportionally, more minority than Han people.

\footnotetext{
${ }^{13}$ As far as I know, none of these criticisms and complaints referred to religious matters. As a whole, religion in Tibetan or Hui inhabited areas contributed almost nothing to the severity of famine, much less than the causes mentioned above, of which the availability of modern transport to convey surplus production was the most influential.
} 


\section{Works Cited}

Ash, Robert. "Squeezing the Peasants: Grain Extraction, Food Consumption and Rural Living Standards in Mao's China." The China Quarterly, vol. 188, Dec. 2006, pp. 959-98. DOI: $10.1017 /$ S0305741006000518

Aubin, Françoise. "Une Chine multinationale." La Chine au XXe siècle, De 1949 à aujourd'hui, edited by Marie-Claire Bergère et al., vol. 2, Fayard, 1990, pp. 287304.

Banister, Judith. China's Changing Population. Stanford UP, 1987.

Becker, Jasper. Hungry Ghosts, China's Secret Famine. John Murray, 1996.

---. La grande famine de Mao. Editions Dagorno, 1998.

Bianco, Lucien. Stalin and Mao: A Comparison of the Russian and Chinese Revolutions. The Chinese UP, 2018.

Dikötter, Frank. Mao's Great Famine. The History of China's Most Devastating Catastrophe, 1958-1962. Bloomsbury, 2010.

Garnaut, Anthony. "The Geography of the Great Leap Famine." Modern China, vol. 40, no. 3 , 2014, pp. 315-48. DOI: $10.1177 / 0097700413507425$

Graziosi, Andrea. Histoire de l'URSS. Nouvelle Clio, 2010.

---. "Stalin's and Mao's Famines: Similarities and Differences." Communism and Hunger: The Ukrainian, Chinese, Kazakh, and Soviet Famines in Comparative Perspective, edited by Andrea Graziosi and Frank E. Sysyn, Canadian Institute of Ukrainian Studies P, 2016, pp. 83-101.

Lardy, Nicolas R. "Chapter 8: The Chinese Economy under Stress, 1958-1965." Cambridge History of China, edited by Roderick MacFarquhar and John K. Fairbank, vol. 14: The People's Republic, Cambridge UP, 1987, pp. 360-97.

$\mathrm{Li}$, Che. "Dajihuang niandai fei zhengchang siwang de ling yizhong jisuan" ["A New Estimate of the Number of Abnormal Deaths at the Time of the Great Famine"]. Yanhuang Chunqiu, vol. 7, 2012, pp. 46-52.

Li, Choh-Ming. The Statistical System of Communist China. U of California P, 1962.

Li, Lillian. Fighting Famine in North China. Stanford UP, 2007.

Li, Zhisui. La vie privée du Président Mao. Plon, 1994.

MacFarquhar, Roderick. The Origins of the Cultural Revolution. Vol. 2: The Great Leap Forward, 1958-1960, Columbia UP, 1983.

Mallory, Walter H. China: Land of Famine. American Geographic Society, 1926.

Manning, Kimberley Ens, and Felix Wemheuer, editors. Eating Bitterness: New Perspectives on China's Great Leap Forward and Famine. UBC Press, 2011.

Ó Gráda, Cormac. Famine, A Short History, Princeton UP, 2009.

Rudnytskyi, O., et al. "Demography of a Man-Made Human Catastrophe: The Case of Massive Famine in Ukraine 1932-1933." Canadian Studies in Population, vol. 42, no. 1-2, 2015, pp. 53-80. DOI: 10.25336/P6FC7G

Teiwes, Frederick C., and Warren Sun. China's Road to Disaster: Mao, Central Politicians, and Provincial Leaders in the Unfolding of the Great Leap Forward, 1955-1959. M.E. Sharpe, 1999.

Union Research Institute. The Case of Peng Teh-Huai, 1959-1968. Union Press, 1968. Wemheuer, Felix. Famine Politics in Maoist China and the Soviet Union. Yale UP, 2014. 
Yang, Dali L. Calamity and Reform in China. State, Rural Society, and Institutional Change since the Great Leap Famine. Stanford UP, 1996.

---. Stèles. La Grande Famine en Chine, 1958-1961. Translated into French by Louis Vincenolles and Sylvie Gentil, Ed. du Seuil, 2012.

---. Tombstone: The Great Chinese Famine, 1958-1962. Translated into English by Stacy Mosher and Guo Han, Farrar, Straus and Giroux, 2012.

Zhonghua Renmin Gongheguo fen sheng dituji (Provincial Atlas of the People's Republic of China), Beijing, Ditu (Editions: “Geographical Maps”), 1977. 